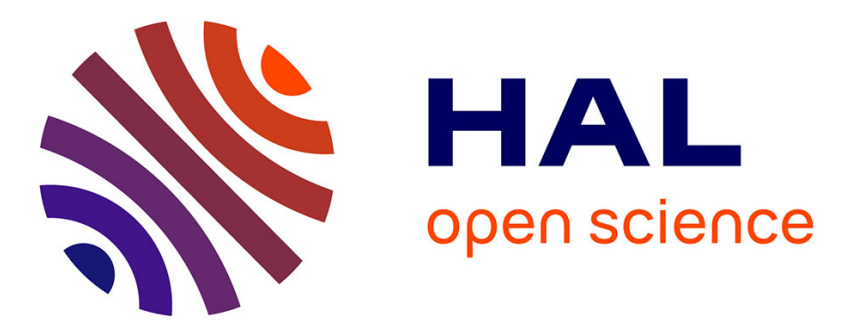

\title{
Stopover ecology of autumn-migrating Bluethroats (Luscinia svecica) in a highly anthropogenic river basin
}

Philippe Fontanilles, Iván de La Hera, Kevin Sourdrille, Florent Lacoste, Christian Kerbiriou

\section{- To cite this version:}

Philippe Fontanilles, Iván de La Hera, Kevin Sourdrille, Florent Lacoste, Christian Kerbiriou. Stopover ecology of autumn-migrating Bluethroats (Luscinia svecica) in a highly anthropogenic river basin. Wilson journal of ornithology, 2020, 161 (1), pp.89-101. 10.1007/s10336-019-01717-z . hal-03102976

\section{HAL Id: hal-03102976 \\ https://hal.science/hal-03102976}

Submitted on 7 Jan 2021

HAL is a multi-disciplinary open access archive for the deposit and dissemination of scientific research documents, whether they are published or not. The documents may come from teaching and research institutions in France or abroad, or from public or private research centers.
L'archive ouverte pluridisciplinaire HAL, est destinée au dépôt et à la diffusion de documents scientifiques de niveau recherche, publiés ou non, émanant des établissements d'enseignement et de recherche français ou étrangers, des laboratoires publics ou privés. 

migration

Philippe Fontanilles ${ }^{1,}$, Iván de la Hera ${ }^{1,2}$, Kevin Sourdrille $^{1}$, Florent Lacoste ${ }^{1}$, Christian Kerbiriou ${ }^{3,4}$

${ }^{1}$ Observatoire d'Intérêt Scientifique Ornithologique (OISO), Cami deth Sailhetou, 65400 Lau Balagnas, France

${ }^{2}$ School of Biological, Earth and Environmental Sciences, University College Cork, Cork, Ireland.

${ }^{3}$ Centre d'Ecologie et des Sciences de la Conservation, UMR7204 MNHN-CNRS-UPMC-Sorbonne Université, 55 Rue Buffon, 75005 Paris, France

${ }^{4}$ Station de Biologie Marine Place de la croix, 29900 Concarneau, France

Corresponding author, e.mail: fontanilles.oiso@laposte.net

Short title: Stopover ecology of Bluethroats

Key words: Luscinia svecica, home range, body condition, habitat selection, corn crop, diet, trophic resources.

\section{Summary}

Wetlands are highly productive habitats that are largely used by many avian species as stopover sites during their migrations. However, these habitats are highly threatened by anthropogenic activities, such as land use changes, the introduction of exotic species and global warming. Further understanding on the spatiotemporal use of wetlands and their surrounding areas by migrating birds is essential to predict how these changes might affect avian en route ecology. We selected a habitat-generalist passerine of conservation concern, the Bluethroat Luscinia svecica, as model of how migratory birds exploit a highly anthropogenic river basin in southwestern France (i.e. Barthes de la Nive) during autumn migration. We captured and radiotracked 29 young Bluethroats in this region to shed light on different aspects of their stopover ecology and behaviour, such as stopover duration, habitat selection and home range size. We also complemented the study with a characterization of Bluethroat diet and arthropod availability in different habitats. Bluethroats positively selected reedbeds (pure or mixed associated with carex), hydrophilous tall grasslands and corn crops. Birds staying more than just one day, 8.4 days on average, used preferably corn crops. Home range sizes were on average 5.8 ha (fixed kernels K95) and high occupancy area (K50) was 1.36 ha with large individual variation. Bluethroats stopping over with low body reserves tended to have larger home ranges and used preferentially corn crops, wet or mesotrophic grasslands and rural paths. Reedbeds were typically used as roosting habitat for the majority of birds, being on average 397 $\mathrm{m}$ apart from their daytime core areas. Short-staying birds tended to show higher body reserves and restricted their activities to a smaller home range (1 ha) in pure and mixed reedbed. The diet of Bluethroats was dominated by ants Hymenoptera Formicidae, Araneidae and Coleoptera that were most abundant in the corn crops. The use of corn crops by migrating Bluethroats during autumn in our study site appears to be a reasonable solution in a highly altered environment. Reducing the use of insecticides in these crops and delaying the harvesting time after mid-October are two measures that could favour Bluethroats and other migratory species while natural wetlands are restored and reedbeds protected from tree encroachment.

ACKNOWLedGements - This work was supported by the Conseil Départemental des Pyrénées Atlantiques, Syndicat Nive Maritime, Villefranque and Bayonne councils. We are particularly grateful to F. Esnault, S. Valles, R. Damestoy and R. Dufourcq. We are extremely thankful to L. Delalande, F. Delfour, A. Glad, M. Janczyszyn-Le Goff, T. Sarraude, for their commitment in the collection of the radiotracking data, to L. Julien for invertebrate sampling, and members of OISO association who made this research possible, especially F. Lartigau. National Museum of Natural History authorized the bird-ringing and radio-tracking scheme. The experiments were complied with the current laws of the country in which they were performed. We also thank two anonymous reviewers who gave insightful comments that improved an early version of the manuscript.

Author contributions: All of the authors collected the data, particularly K.S. the habitat map, F.L. and C.K. diet bird and arthropod availability. P.F., I.H. and C.K. analyzed the data, designed the methods and conducted the research. All of the authors took part in the formulation of the questions and hypotheses. P.F. wrote the paper in cooperation with I.H. and C.K.

Conflict of interest: The authors declare that they have no conflicts of interest.

Ethics statement: All data and information from external sources used for the analyses and preparation of the manuscript are properly cited. The conclusions are entirely based on our own results. All applicable international, national, and/or institutional guidelines for the care and use of animals were followed. 
The global conservation of migratory birds not only relies on the protection of their breeding and wintering habitats, but also on the presence of suitable stopover sites along their migratory routes (Hutto 2000, Young 2000, Newton 2008). Coastal marshes, estuaries and other types of wetlands are highly productive habitats largely used during migration by waterbirds and other avian species, constituting key conservation areas (Czech and Parsons 2002). Wetland habitats experienced a dramatic reduction and an increased fragmentation during the 20th century, mainly as a consequence of the pressure of human activities, such as urbanization and the drainage for agricultural use (von Behren 2007; Whited et al 2000; Czech and Parsons 2002). As a result, wetlands usually remain now embedded in a complex and highly-altered human matrix, where every year migrating birds rest and search for food to undertake their next flight bout.

The wetland remnants that many birds use as stopover sites are normally small and face some common problems that, in some cases, can be mitigated by human intervention. For example, many wetland managers implement measurements to avoid clogging, which could lead to bush encroachment and the progressive disappearance of marsh vegetation (Clark and Wilson 2001); while the control of invasive and exotic species, that can alter wetland biodiversity and functioning, is also a common practice (Fontanilles et al. 2014; Arizaga et al. 2013). These measurements would increase the quality and carrying capacity of the wetlands, which would be very beneficial for migrating birds (e.g. fuel acquisition; Delingat and Dierschke 2000). Another aspect that has hitherto received little attention is the potential management and planning of the areas surrounding the wetland. These adjacent areas might be intensively used by migrants given the restricted size of wetland patches and the potential high intra and interspecifc competition with other migratory and resident individual birds. This situation could be particularly exacerbated during the migration peaks, when large number of individuals can meet together in a single location (Newton, 2004). Such circumstance predicts that many migrants will be forced to expand their home-ranges and use alternative habitats out of the wetland. In this context, identifying which alternative habitats are positively selected by migrating birds during their brief stopovers would be essential to design buffer areas that best meet the requirements for these en route migrants. However, our knowledge of the stopover ecology and behaviour of migratory birds is still very limited.

In this study, we analysed the stopover ecology of migrating Bluethroats Luscinia svecica in Barthes de la Nive (France) during autumn migration. Barthes de la Nive is a mosaic of wetlands, riparian woodlands and farmlands located near the Adour River mouth in the Southwestern Atlantic coast of France. The scattered wetlands in this region attract a large diversity of both aquatic and non-aquatic birds during migration periods (Fontanilles et al. 2011). The only radiotracking study carried out in this area so far showed that the globally endangered Aquatic Warbler Acrocephalus paludicola had a strong preference for reedbeds but, to a lesser extent, it also made use of some farmlands (Fontanilles et al. 2014). This highlights the relevance that the surrounding matrix might have even for a wetland specialist as the Aquatic warbler. Conversely, Bluethroats are migratory birds that can use a large range of habitats, mainly reedbeds and marshlands (Arizaga et al. 2006; Musseau et al. 2017), but also bushlands, woodland and farming habitats (Cramp 1988; Cornulier et al. 1997; Chiron, 2017, Berndt and Hölzl 2012), making it an interesting model to study its stopover ecology and habitat selection during migration. Arizaga et al. (2011) radiotracked 20 autumn-migrating Bluethroats in Txingudi (North Spain), a wetland located less than 30km away from Barthes de la Nive. Their results showed a strong selection for reedbeds, lowhalophytic vegetation and tidal flats. However, Txingudi is located in a more urbanized environment that probably greatly restricts bird movements, and its proximity to the river mouth allows the presence of habitats that are lacking in Barthes de la Nive (e.g. halophytic vegetation). On the other hand, bird ringing information obtained for both wetlands during autumn migration showed dramatic differences in the number of selfrecoveries, which are much more usual in Txingudi than in Barthes de la Nive (Arizaga et al. 2011; Fontanilles unpublished data). These differences could be a consequence of a longer stopover duration of Bluethroats in Txingudi than in Barthes de la Nive, but they could also be caused by the existence of larger home ranges in Barthes de la Nive, something that would be possible in its much less urbanized surrounding. All these aspects suggest a different stopover ecology and behaviour of Bluethroats between both wetlands in spite of their geographic proximity that remains still unexplored.

In order to better understand the stopover ecology of the Bluethroat in Barthes de la Nive, we performed a radiotracking study during autumn migration that aims to shed light on (1) the stopover duration and the proximate factors that affect it, (2) habitat selection and home range sizes, and (3) we complemented the study with an analysis of Bluethroat diet and the availability of food resources. Although Bluethroats are not globally threatened, some populations have been considered to be under high risk of extinction (Huntley et al. 2007). Consequently, we expect that the spatial information generated in this study could be valuable for the competent authorities to design management practices out of the wetlands patches that could contribute to the conservation of Bluethroats and other birds during their migrations. 


\section{Bluethroat trapping and body measurements}

Mist-netting sessions were performed from mid-August to late September when migrating Bluethroats stopover in this region during their post-breeding migratory period. Note that Bluethroats do not breed in Barthes de la Nive or use it for moulting (Fontanilles et al. 2011). Ringing sessions took place in five different locations across the study area: four wetlands and one corn crop (see details in Supplementary Material Fig. A1, Ap. 3, Table 2). These five sites were reasonably distant each other to reduce potential geographic bias and, according to previous studies (Fontanilles et al. 2011, Fontanilles 2014), they represent the two main habitats (i.e. reedbed, corn crops) where Bluethroats occur during their stopover at Barthes de la Nive.

To maximize the number of captures, we used one male song playback from 30 minutes before dawn (when mist-nets were open) until a tagged bird was released (when mist-nets were furled). By using the tape lures only 30 minutes before sunrise, we reduced the possibilities of forcing the landing of migrating Bluethroats and we expected to capture only birds that decided voluntarily to stop over in our study area (Schaub 1999; Arizaga et al. 2015). During our ringing sessions, we captured 58 Bluethroats (28 in 2014 and 30 in 2015).

Several morphological measurements were taken from each bird in order to obtain a composite index of bird body size (Freeman and Jackson 1990, Tellería et al. 2013, see Supplementary Material). We also recorded body mass $( \pm 0.1 \mathrm{~g})$ and standard scores of fat and muscle (Busse 2000). Body size-corrected measurements of body mass were used to estimate the relative quantity of body reserves carried by each Bluethroat. This was done using linear regression of body mass on body size (see Supplementary Material Ap. 2, Fig. A2), where individuals with more body reserves showed more positive residuals (Salewski et al. 2009).

\section{Radio tracking information}

Out of the 58 Bluethroats captured, 29 juveniles were equipped with a radio-transmitter, with a minimum of 4 radiotagged individuals in each of the 5 ringing sites $(25$ birds were trapped in the reedbeds and 4 in the corn crops; see details in Supplementary Material, Ap. 3, Table A2). Life expectancy of the emitters is typically more than 17 days and the average detection distance is 80-300 meters. We only tagged first-year birds because the study site is mainly used by first-year birds; and because juveniles face their first autumn migration and, consequently, their habitat choice cannot be influenced by previous experience (Piper 2011).

On the day of capture, monitoring of tagged Bluethroats started at least one hour after the bird was released in order to avoid bias linked to potential stress behaviour. For birds that stayed in the area the following days after capture (see below), they were normally monitored $8 \mathrm{~h}$ per day during, normally, 3-4 days in long-staying individuals. After this period, we checked the presence every day, but the intensity of the radiotracking typically got reduced and depended on other duties associated with the project, particularly, the trapping and monitoring of other individuals (see Supplementary Material Ap.3 for more details).

The positions of the birds were obtained normally by triangulation (3 vectors taken consecutively within less than 10 minutes), but we used bi-angulation in those cases in which landscape barriers (like canals, rivers or dense vegetation) impeded taking more than two informative vectors, or just one vector plus an estimation of the actual distance to the bird when this was observed. We used Sika receivers (Biotrack Ltd) and Yagi antennas to find the birds, and vectors were delimited using a GPS (to determine observer position) and a compass (to obtain magnetic Azimuth). All this information was computerized using the software Cartoexploreur, and we considered the centroid of the triangle determined by the three corresponding vectors as the most likely geographic position of the bird, or the intersections between lines when two vectors were only available. Prior to the start of radiotracking, observers were trained in the study area and the accuracy of the triangulation method was assessed. The average error found in the estimation of the positions of transmitters hidden in the study area was $14.5 \pm 1$ se $m(n=69)$, which can be considered enough given the purpose of studying main habitat selection. 


\section{Stopover duration and its determinants}

We used the number of days spent by each Bluethroat after being tagged (assessed by the radiotracking survey) as a proxy of stopover duration. This approach is expected to provide a better idea than ringing recaptures on how long Bluethroats stopover in Barthes de la Nive, since ring-recovery data are spatially restricted, have a lower detection probability and strongly depend on a good sampling strategy (Chernetsov 2012). According to the non-Gaussian distribution of stopover durations (see Fig. A3) we performed non parametric tests (Wilcoxon tests, Kruskal-Wallis tests and Spearman correlations) to evaluate which factors (year, sex, site, date of capture, muscle development, fat accumulation and body condition) better correlated with the observed variation in the length of the stay of Bluethroats.

\section{Habitat selection}

Initially, we tested whether Bluethroat locations were randomly distributed among habitats. We applied the quadrats method (Zaminetti 2005) by defining a grid of K squares $100 \times 100$ m enveloping all the radio-tracking points. The theoretical distribution $\mathrm{K}_{\mathrm{th}}(\mathrm{n})$ was obtained following the Poisson's law: $\mathrm{K}_{\mathrm{nth}}=\left[\mathrm{K}^{*}\left(\mathrm{D}^{\mathrm{n}} / \mathrm{n} !\right)\right]^{*} \exp (-\mathrm{D})$ where $n$ is the number of points per mesh, $K(n)$ the number of stitches having $n$ points, $N$ is the total number of locations and D is the average density of locations by cell that is defined as $\mathrm{N}$ divided by $\mathrm{K}$. The existence of significant differences between the two distributions (i.e. $K(n)$ and $K_{t h}(n)$ ) was assessed using a KolmogorovSmirnov test.

Secondly, for assessing habitat selection, we calculated for each habitat the electivity index of Jacobs (1974) $I_{h}=$ $\mathrm{U}-\mathrm{D} /(\mathrm{U}+\mathrm{D}-2 \mathrm{U} * \mathrm{D})$ where $\mathrm{U}$ is the proportion of locations in habitat $\mathrm{h}$ and $\mathrm{D}$ the proportion of this habitat in the study area. The index ranges between -1 (strong rejection of a particular habitat) and 1 (strong selection). We used the proportion of locations instead of the proportion of areas in core areas to take into account the edge effects and to be more precise with the actual habitat used. We excluded habitats poorly represented showing less than 5 locations.

\section{Home range estimates}

The overall home range size of each individual Bluethroat was estimated by the model of 95\% kernel (K95; Worton 1989). The K95 approach is usually used in this type of studies, which would allow between study comparisons (Börger et al. 2006). Areas of high occupancy were also estimated using the 50\% kernel (K50), considered as a good estimator of core areas (Börger et al. 2006). We calculated the overall home range with all the locations for each bird and also for each day when there was a minimum of 10 positions. Home range sizes were processed using the Ranges 8v2.10 software (Anatrack ltd).

\section{Home range analysis}

We explored whether overall home range size varied in relation to the proportion of habitats contained within it (10 habitat variables, see Table 1), several metrics of heterogeneity (mean patch size, number of habitat or Shanon index perform of patch size distribution) and individual-associated variables (body condition, sex and stopover duration). For that purpose, we performed General Linear Models (GLM) using the home range size (50\% kernel and $95 \%$ kernel) as a response variable, while habitat cover and individual-associated variables were included as explanatory variables. According to the distribution of home range size (positive long tail distribution), we applied a negative binomial error distribution to the GLM in order to minimize issues related to the over-dispersion ratio in the models (i.e. as close as possible to 1; Zuur et al. 2009). Following a multi model inference (Burnham et al. 2011; Grueber et al. 2011), we generated a set of candidate models containing all possible variable combinations and ranked them by corrected Akaike information criterion (AICc) using the dredge function (R package MuMIn). We only integrated the models complying with the following conditions: (i) models do not include simultaneously correlated covariates $\left(\mathrm{R}^{2}>0.7\right)$ and (ii) models do not include more than three variables to avoid over-parameterization due to the limited data set. Since the simultaneous inclusion of habitat cover and measures of habitat heterogeneity generated important multi-collinearity problems, we decided to perform two separate modelling: one with habitat cover within the home range and individualassociated variables; and a second one, with measures of habitat heterogeneity and individual-associated variables (results of this second modelling are shown in Appendix 5). We restricted this set of models using a cut-off of 2 AICc. The modelling with habitat cover resulted in 4 and 3 top models for 50\% Kernel and 95\% Kernel, respectively (see Supplementary Material Ap. 5, Table A3). The modelling with measures of habitat heterogeneity resulted in 4 and 2 top models for 50\% Kernel and 95\% Kernel, respectively (see Supplementary Material Ap. 5).

Following the same approach, we explored whether daily home range size (with a minimum of 10 positions) varied in relation to habitat cover within home range, individual-associated variables. According to the hierarchical structure of this data set (radio-tagged individuals survey each day), we treated the variable "individual identity" as a random effect, while considering the other explanatory variables (home range and individual-associated variables) as fixed effects (Zuur et al. 2009). Following a multi model inference using General Linear Mixed Models with a negative binomial error distribution, the daily home range analyses resulted in a total of 2 and 3 top models for the 50\% and 95\% kernel, respectively (see Supplementary Material Ap. 5, Table A). We also used a secondary method based on PCA analysis detailed in Supplementary Material Ap. 6. 


\section{Roosting habitat selection}

To provide information on roosting behaviour, we identified the habitats used between sunset and sunrise (roosting locations) and also estimated their distance to the daytime, potential, foraging areas. We identified the habitat of all those locations on the vegetation map. We compared the proportions of roosting locations occurring in each habitat to identify the most used by a posteriori Wilcoxon test. For birds flying to a roosting location far away from the area used during daytime hours, we calculated the distance between the centroid of the home range exploited during daytime hours and the core of roosting locations. We then compared the proportions of habitats between these two areas (home range during daytime hours vs. roosting locations core) by a posteriori Wilcoxon test.

\section{Diet of Bluethroat}

To try to elucidate why birds tend to select specific habitats, we analysed their diet and the invertebrate availability. We collected 105 faecal samples during ringing operations for all sites in $2015(n=52)$ and 2014 $(n=30)$ and only in Urdains in $2012(n=23)$. All remains identified in faeces were used to estimate the minimum number of prey items and the occurrence of each taxonomic group within each sample. While some bias in diet analyses was possible because small or soft-bodied preys are less easily detected, strong correlation has been found between prey remains in droppings and the actual composition of the diet (Davies 1977a, 1977b). We also assessed prey biomass using predictive models based on the relationship between body length and mass of terrestrial arthropods (Hodar 1996; see Supplementary Material Ap. 7 for additional details). We explored which factors influenced the prey abundance, testing explicitly the effects of age (young vs adult birds), sex and day using a Generalized Linear Model (GLM) with a Poisson error distribution. P-values were corrected for overdispersion. Only taxa representing more than $2 \%$ of the prey abundance were considered

\section{Invertebrate availability between habitats}

We estimated the variation in the abundance of (near) ground invertebrates (the main feeding substrate of Bluethroats) between the two main habitats occupied by Bluethroats (corn crops and reedbeds). Given the large extension of the study area, we decided to focus our invertebrate sampling on three of the five trapping areas: the corn crop area, and Villefranque and Urdains reedbeds (Fig. A1). The corn crops in the other bank of the Nive River had similar plantation and exploitation, so we assumed them to have a similar invertebrate availability. We used 3 standardized coloured (yellow, white, blue) bowl traps and a pitfall glass per station (for a total of 12 stations, 6 in the corn crops, 3 in each reedbed). All stations were sampled simultaneously at 3 temporal stages in August 2015. Traps were deployed for four days. For more details, see Supplementary Material Ap. 8. For subsequent analyses, we pooled together the data of the three bowl traps of each station. We focused the analyses on those taxa whose remains had been found in faeces of trapped Bluethroats. We compared invertebrate availability, abundance and biomass between the two reedbeds and the corn crop using General Linear Models with a Poisson error distribution.

Unless specified, mean values are given \pm se (standard error).

\section{RESULTS}

\section{Stopover duration and body condition effect}

Tagged Bluethroats stayed 5 days ( \pm 1 se; range 1-20) on average upon capture in Barthes de la Nive, but showing a clearly non-Gaussian distribution where up to 13 individuals left the study area the next night after being captured (Fig. A3). The remaining 16 Bluethroats stayed on average $8.4 \pm 1.3$ days (see Table A1, Fig. A3).

Observed variation in stopover duration did not differ significantly between years $(\mathrm{W}=91, \mathrm{p}=0.536)$, sites (Kruskal-Wallis H $(3,29)=1.11, \mathrm{p}=0.774)$, sex $(\mathrm{W}=133, \mathrm{p}=0.189)$, date of capture ( $\mathrm{r}$ Spearman= $-0.11, \mathrm{t}_{27}=-$ $0.59, \mathrm{p}=0.558$ ) or muscle development $\left(\mathrm{r}\right.$ Spearman $\left.=-0.17, \mathrm{t}_{27}=-0.92, \mathrm{p}=0.365\right)$. The fat score was significantly associated with stopover duration ( $\mathrm{r}$ Spearman $=-0.40, \mathrm{t}_{27}=-2.24, \mathrm{p}=0.034$ ). However, the individual trait that better explained stopover duration was the quantity of body reserves, which was estimated from the residuals of body mass on body size (effects of body size on body mass: $\beta=0.888, \mathrm{~F}_{1,27}=100.9, \mathrm{p}<0.001$ ). Thus, Bluethroats with relatively more body reserves for a given body size left the Nive basin earlier on average ( $\mathrm{r}$ Spearman= $0.59, \mathrm{t}_{27}=-3.78, \mathrm{p}<0.001$; Fig. 1) than birds with relatively less body reserves. Additionally, we analysed whether stopover duration differed between habitats used. Irrespective of where they were trapped, birds that used corn crops during their stay remained significantly ( $\mathrm{W}=23, \mathrm{p}<0.001)$ longer $(10$ days $\pm 1.1 \mathrm{se}, \mathrm{n}=10)$ in the area than those not using this habitat type (2.7days \pm 0.6 se, n=19; see Fig. 2). .

\section{Habitats selection}

The 29 radiotracked juvenile Bluethroats provided 1718 positions during their stay in our study site. Bluethroat locations were not randomly distributed among habitats. Their distributions differed significantly from the theoretical null distributions (Kolmogorov-Smirnov test $\mathrm{D}=0.896, \mathrm{p}<0.0001$ ). The main habitats used by all birds were corn crops and reedbeds, either pure or mixed (Fig. 3). The distribution differed between birds staying one day, which preferred pure reedbed $(\mathrm{W}=55.5, \mathrm{p}=0.034)$, and the rest, which positively selected the 
corn crops $(\mathrm{W}=162, \mathrm{p}=0.013)$. The birds stopping over for just one day made use of less habitat types $(2.2 \pm 0.3$ stay, there were no differences between them in the preferred habitat and number of them (tests Wilcoxon, $\mathrm{p}>$ 0.05, Fig.A4). Regarding the available habitats (Fig. 4), Bluethroats strongly positively selected pure and mixed reedbeds, corn crops and hydrophilous tall grasslands. They moderately selected paths, wooded reedbeds and mesophic grasslands, while they avoided water, railways, ferns, wet grasslands, houses, woodlands and hay meadows.

\section{Home range analysis}

The average number of locations per individual was $59.2 \pm 9$ (22.5 \pm 1.6 for birds staying one day, and $89 \pm 12$ for birds staying longer). The average overall K95 home range was $5.8 \pm 1.8$ ha with a large variation between individuals (standard deviation 9.9, range 0.016-46.5). The core area (i.e. K50) was on average $1.36 \pm 0.35$ ha (standard deviation 1.87, range 0.004-7.6). K95 areas were larger in birds staying more than one day $(9.72 \pm 3$ ha) than in birds stopping over just one day $(1.07 \pm 0.46 \mathrm{ha} ; \mathrm{W}=23, \mathrm{p}<0.001)$. Similar results were obtained for the K50 core area: $0.28 \pm 0.12$ ha for long-staying birds, and $2.24 \pm 0.53$ ha for birds staying only 1 day $(\mathrm{W}=18$, $\mathrm{p}<0.001)$.

Bluethroats with greater overall home range included more wet grassland, woodland and mesophilic grassland within their range, and also exhibited longer stopover duration. On the other hand, Bluethroats with smaller overall home range exhibited larger quantities of body reserves and occupied areas with a higher proportion of reedbed (Table 2). Analyses performed for daily home ranges highlighted that Bluethroats with greater home range included more hay grasslands, open water, and woodlands; while Bluethroat with smaller daily home range occupied areas with a higher proportion of crop fields, natural paths and pure reedbeds (Table 2). In addition, analyses performed with measures of habitat heterogeneity, showed that Bluethroats with greater overall home range exhibited a more diversified home range (Appendix 5). According to AICc, measures of habitat heterogeneity performed better than habitat cover variables for K95, while the opposite was true for K50 (Appendix 5).

A second analytical method based on PCA analysis gave similar results (see Supplementary Material Ap. 6).

\section{Roosting habitat selection}

We identified the overnight habitat in 26 Bluethroats. Pure reedbed was the main roosting habitat, with $44.2 \%$ of the nights (Fig. 5). Mixed or wooded reedbeds were also well-represented within the roosting habitats, representing $17.5 \%$ and $16.8 \%$, respectively. So, reedbeds (pure, mixed and wood reedbed) were the preferred habitats for roosting $(80.1 \pm 8 \%$ of nights) in 23 birds that stayed for at least one night. Corn crops were also used by 5 birds but less frequently than reedbeds: $13.1 \pm 6 \%$ of nights.

$83 \%$ of birds spending the night in reedbeds (pure, mixed and wood reedbed) occupied the same reedbed during the day. This took place in $59 \pm 9 \%$ of the nights (Fig. 6). This particularly concerned the 13 Bluethroats which stopped for one day. Individuals staying for at least 2 days showed relatively predictable movements and selected repeatedly the same areas during the night. $27 \%$ of the birds (7) spent overnight in a reedbed (Urdains or Villefranque) and normally moved during the day to a corn crop. This was noticed for $12.5 \pm 5 \%$ of the nights. We calculated the distance between roosting core areas and daytime foraging core areas. Birds flew on average $397 \pm 33 \mathrm{~m}$ to reach its roosting location $(\mathrm{n}=10$, range $80-692 \mathrm{~m})$. Five birds also used corn crops to stay during the night after using it also during the daytime (19 nights).

\section{Diet analyses and available invertebrates within habitats}

We analysed Bluethroat diet and invertebrate availability to explore foraging preferences. We obtained 105 faecal samples: 84 faecal samples from first year birds and 21 from adults, 55 from males and 47 from females. A total of 431 prey items were identified, $4.1 \pm 0.8$ on average per dropping. We found 14 orders of invertebrates $(2.2 \pm 0.3$ on average per sample). The diet of Bluethroats was dominated by ants Hymenoptera Formicidae, representing $45.5 \%$ of preys and occurring in 54\% of the samples (Table 3). Araneidae was the second most abundant group (20.4\%) with a similar occurrence to ants $(53 \%)$; and Coleoptera was the third most common group (10.2\% of all preys and $31 \%$ of the samples). These two last taxa were the main contributors to the consumed biomass, representing $64.7 \%$ and $14.9 \%$, respectively. We did not detect any significant effects of Bluethroat age and sex on prey abundance. We did also observe that Cicadellidae was less consumed over time (Table 3).

Corn crops hosted significantly more invertebrates and biomass than reedbeds for Coleoptera, Diptera and Araneida in pitfalls, and for Cicadellidae in bowls (Table 4). Corn crops also had higher availability of notFormicidae Hymenoptera than Urdains in bowls, but less than Villefranque. Finally, Formicidae was more abundant in Urdains than in the other two sites. 


\section{Variation in stopover duration and home range size}

Bluethroats showed large individual variation in their stopover duration and home range size in Barthes de la Nive. Observed mean values differed from those obtained by Arizaga et al. (2013). Thus, stopover duration was shorter and home range larger in Barthes de la Nive (mean stopover duration of 5 days and mean home range size of $5.8 \mathrm{ha}$ ) than in Txingudi (9.6 days and 2 ha, respectively). Differences in stopover duration between these two sites were mediated by the fact that $45 \%$ of the radiotracked Bluethroats in Barthes de la Nive apparently departed the following night after capture, a circumstance that never took place in Txingudi (Fig. A3).). If these short-staying individuals were excluded from the calculations, the stopover duration in Barthes de la Nive (i.e. 8.4 days) would conform better to the values obtained in Txingudi. After the signal of a bird disappeared from the place it was last detected, we carefully explored the whole study area by car the following day in its search, and sporadically the following days. This makes us very confident that the stopover duration estimates obtained in Barthes de la Nive are reliable. Likewise, the fact that only one of the 29 radiotracked Bluethroats stayed longer than the life-expectancy of the transmitter would not alter these between-site differences or the general conclusions of our study (see below). Actually supporting the longer stopover duration of Bluethroats in Txingudi, it was slightly higher (3 out of 20) the number of Bluethroats whose stay reached the expected functional life of the transmitters in this wetland than in Barthes de la Nive.

It could be argued that the higher number of short-staying Bluethroats in Barthes de la Nive was caused by the use of playbacks during the trapping sessions, which were not implemented in Txingudi. However, current evidence would not support this hypothesis, since the use of playbacks typically attracts Bluethroats with lower body reserves (Arizaga et al. 2015) and, as our results show, birds with less fuel loads would tend to have longer stopover durations (Alerstam and Lindström 1990; Salewski and Schaub 2007). This bias of playback use on the body reserve loads of autumn migrating Bluethroats was consistent in the three wetlands (on the Bay of Biscay, Gironde, Txingudi, Urdaibai) analysed by Arizaga et al. (2015) that are geographically close to Barthes de la Nive. If Bluethroats do show transient vs. non-transient divergent behaviours during migration as have been described for other migratory species (Rappole and Warner 1976), playbacks might have also biased stopover duration estimates if they do preferentially attract transient individuals. Again, the results obtained by Arizaga et al. (2015) do not support this possibility, since playbacks do not seem to affect the number of Bluethroat recaptures, and this would be an expected outcome if playbacks promoted the capture of more transient individuals that will have less recapture prospects. Likewise and contrary to what would be expected for their transient condition, these short-staying individuals did not move as much as would be expected after being trapped in Barthes de la Nive, and their first-day home range did not differ significantly from that observed for long-staying conspecifics.

). Additionally, overall home ranges are nearly twice to three times larger in Barthes de la Nive than in Txingudi (Arizaga et al. 2013). Musseau et al. (2017) also found home ranges of similar size to Arizaga et al. (2013) in moulting Bluethroats.). These contrasting differences between Txingudi and Barthes de la Nive are very likely mediated by the strong differences in the degree of urbanization and habitat composition that seem to have profound consequences in the stopover behaviour of Bluethroats between two relatively close locations.

\section{Habitat and roosting site selection}

Migrating Bluethroats in Barthes de la Nive strongly selected reedbeds (pure and mixed) and other hydrophilic natural grasslands, which concurs with the favourite habitat that Arizaga et al. (2013) and Musseau et al. (2017) found for migrating and moulting conspecifics, respectively. Much less known was the preference of migrating Bluethroats for corn crops, although one study had detected this species in this crop type during migration (Gottschalk \& Cover 2016) and some populations of Bluethroats seem to thrive and even breed successfully in some agricultural fields, such as oilseed rape crops (Cornulier et al. 1997; Berndt and Hölzl 2012, Chiron 2017). We did not find the preference of Bluethroats for tidal mudflats or low-halophytic vegetation described in other studies (Arizaga et al. 2013; Godet et al. 2015; Musseau et al 2017), but the representation of these habitats in Barthes de la Nive is relatively limited, which could explain this lack of use.

Our results showed that home-range size is smaller when birds occupied reedbeds (for overall home ranges) and corn crops (for daily home ranges). A potential explanation for this result is that these habitats might offer more trophic resources, which would prevent birds from moving long distances in search for food (Bibby and Green 1980; Chernetsov et al. 2004). Another complementary hypothesis for the higher occurrence of Bluethroats in these two habitat is that, given their dense structure, they could also provide a suitable shelter, not only for roosting during the night but also to rest during daytime between migration flight bouts. The use of reedbeds as roosting habitat has been described before in Bluethroats (Eybert et al. 2004; Harmange et al. 2016) and our study confirmed this preference and suggested that corn crops might occasionally play a similar role. In contrast, long-staying Bluethroats seem to expand their home range probably because they are in high demand of food for 
refueling and, perhaps, because of the competition with conspecifics and other species (Chernetsov and Titov 2001; Fransson et al. 2008).

If home-range size is considered a proxy of habitat quality, inland reedbeds could be interpreted as a refuge or a more optimal habitat than corn crops, which might represent the most-commonly available substitution habitat (Godet et al. 2018), where birds needing to refuel would move due to competition and the limited availability of reedbeds.

In our site, Bluethroats encounter also some potentially unsuitable habitats such as woodlands, open water, mowngrasslands and infrastructures (house, road, railway) that would explain why they had to fly away a relatively long distance from their preferred roosts (Harmange et al. 2016), expanding their home range size. Similar patterns have been shown in Briere for breeding Bluethroats (Godet et al. 2015).

We did not detect any difference between males and females in home range size, flight distance or stopover duration. Typically, small-sized, young and female Bluethroats are subordinated to large, adult and male conspecifics, respectively (Lindström et al. 1990, Moore et al. 2003). Our results suggest that Barthes de la Nive was occupied, not under an ideal despotic distribution, but under an ideal free distribution, where home range size would be determined by its habitat composition.

\section{Diet of birds and invertebrate availability}

The diet description in our study site fitted well with the trophic characterization made in other Bluethroat studies (Allano et al. 1998; Orłowski et al. 2014; Musseau et al. 2017). In decreasing order of importance, our study showed the relevance of Hymenoptera Formicidae (40.6\% of prey; $8.7 \%$ of biomass), Diptera (resp. $14 \%$ and $6.5 \%)$, Coleoptera $(13.7 \%, 40 \%)$ and Araneae $(9.4 \%, 22.5 \%)$. Bluethroats typically forage on the ground (Orlowski et al. 2014, Allano et al. 1998, Cramp 1988) where Formicidae are particularly abundant. As in other agricultural farms (Cornouiller et al. 1997), corn crops showed a very high insect abundance and biomass, which could explain why Bluethroats positively selected this habitat. Again and as a consequence of the relative scarcity of intertidal habitats, arthropods such as Malacostraca Amphipoda, were absent from the diet of Bluethroat in Barthes de la Nive, although they have been found in other studies (Musseau et al. 2017; Allano et al. 1998).

\section{Habitat management implications}

Our study confirmed the importance of wetlands and their associated reedbeds in Barthes de la Nive for migrating Bluethroats, as it was also shown for other bird species stopping over in the region (Fontanilles et al. 2014). This reaffirms the need to conserve and potentially expand these valuable habitats, whose largest remnants in Southwestern France persist in the Nive/Adour river basin, and are mainly threatened by clogging and bush encroachment, particularly by invasive exotic tree species (i.e. Acer negundo, Baccharis halimifolia). So, tree expansion must be controlled in reedbeds to maintain an open wetland.

Likewise, our results unexpectedly revealed a positive selection of corn crops by Bluethroats. The tall and dense arrangement of corn plants resemble the habitat structure of reedbeds. However, corn crops do not seem to constitute an ecological trap but a substitution habitat, (Godet et al 2018) an human-induced opportunity for migrating birds. Anyway, further research would be required to further understand this this selection process and whether it also takes place in other sites. Our preliminary results suggest that corn crops would provide plenty of food resources and a suitable shelter for birds stopping over in Barthes de la Nive. Our study using the Bluethroat as model species raises the question of how other bird species respond to the presence of corn crops during their stopovers. The corn crops of Barthes de la Nive are used by a large group of migratory species (Fontanilles not published), so that measures to maintain or increase the suitability of this common crop for birds around the limited wetland remnants should be encouraged. Among them, promoting organic farming and postponing the harvesting time after mid-October, when most insectivorous migrants are in or near their southern wintering quarters, would be relatively easy to implement and might have immediate payoff (Dänhardt et al. 2010). 


\section{REFERENCES}

Alerstam T, Lindström C (1990). Optimal bird migration: the relative importance of time, energy and safety. In: Gwiner E (eds). Bird migration: the physiology and ecophysiology. Springer-Verlag Heidelberg, Berlin, pp. 331-351

Allano L, Bonnet P, Constant P, Eybert M (1988). Premières données sur le régime alimentaire des jeunes gorgebleues (Luscinia svecica namnetum, Mayaud) au nid dans un marais salant exploité (Guérande, LoireAtlantique). C. R. Acad. Sci. Paris $306: 369-374$

Arizaga J, Alonso D, Campos F, Unamuno JM, Monteagudo A, Fernandez G, Carregal XM, Barba E (2006). Do subspecies of bluethroat Luscinia svecica show a geographic segregation during the autumn migration period in Spain? Ardeola 53: 285-291

Arizaga J, Barba E, Alonso D, Vilches A (2010). Stopover of Bluethroats (Luscinia svecica cyanecula) in northern Iberia during the autumn migration period. Ardeola 57: 69-85

Arizaga J, Mendiburu A, Alonso D, Cuadrado JF., Jauregi JI, Sánchez JM (2011). A comparison of stopover behavior of two subspecies of the Bluethroat (Luscinia svecica) in Northern Iberia during the autumn migration period. Ardeola 58: 251-265

Arizaga J, Andueza M, Tamayo I (2013). Spatial behaviour and habitat use of first-year Bluethroats Luscinia svecica stopping over at coastal marshes during the autumn migration period. Acta Ornithologica 48: 17-25

Arizaga J, Musseau R, Laso M, Esparza X, Unamuno E, Azkona A \& Fontanilles P (2015). Biases associated with the use of a playback in stopover ecology studies in small passerine birds. Bird study 62, Issue 2: 280-284

Barg JJ, Jones J, Robertson RJ (2005). Describing breeding territories of migratory passerines: suggestions for sampling, choice of estimator, and delineation of core areas. Journal of Animal Ecology 74:139- 149

Berndt AM, Hölzel N (2012). Energy crops as a new bird habitat utilization of oilseed rape fields by the rare Bluethroat (Luscinia svecica). Biodiversity Conservation 21: 527-541

Bibby CJ, Green RE (1980). Foraging behaviour of migrant pied flycatchers, Ficedula hypoleuca, on temporary territories. J. Anim. Ecol. 49: 507-521

Börger L, Francon N, De Michele G, Gantz A, Meschi F, Manica A, Lovari S Coulson (T) 2006. Effects of sampling regime on the mean and variance of home range size estimates. Journal of Animal Ecology 75: 13931405

Both C, Bouwhuis S, Lessells CM Visser ME (2006). Climate change and population declines in a long-distance migratory bird. Nature, 441: 81-83

Burnham KP, Anderson DR, Huyvaert KP (2011). AIC model selection and multimodel inference in behavioral ecology: some background, observations, and comparisons. Behavioural Ecology and Sociobiology, 65, 23-35

Busse P (2000). Bird Station Manuel. SE European Bird Migration Network, Gdansk

Chernetsov N (2012). Passerines migration: stopovers and Flight. Ed. Springer

Chernetsov N, Manukyan A (2000). Foraging strategy of the Sedge Warbler (Acrocephalus schoenobaenus) on migration. Vogelwarte 40: 189-197

Chernetsov N, Titov NV (2001). Movement patterns of European reed warblers Acrocephalus scirpaceus and sedge warblers A. schoenobaenus before and during autumn migration. Ardea 89: 509-515

Chernetsov N, Mukhin A, Ktitorov P (2004). Contrasting spatial behaviour of two long-distance passerine migrants at spring stopovers. Avian Ecol. Behav. 12: 53-61

Chiron D, (2017). Range extension of the Bluethroat Luscinia svecica namnetum towards intensive farming habitats in Central western France. Alauda 85 (2): 81-91 
Clark DL, Wilson MV (2001). Fire, mowing, and hand-removal of woody species in restoring a native wetland prairie in the Willamette valley of Oregon. Wetlands 21(1):135-144

Cornulier Th, Bernard R, De, Arroyo B, Bretagnolle V (1997). Extension géographique et écologique de la Gorgebleue à miroir Luscinia svecica dans le Centre-Ouest de la France. Alauda 65 (1): 1-6

Cramp S (1988). The Birds of the Western Palearctic. Oxford: Oxford University Press. Vol. 5.

Czech HA, Parsons CK (2002). Agricultural Wetlands and Waterbirds: A Review Author(s): Waterbirds: The International Journal of Waterbird Biology. Special Publication 2: Managing Wetlands for Waterbirds: Integrated Approaches 25:56-65

Dänhardt J, Green M, Lindström Å, Rundlöf M, Smith HG (2010). Farmland as stopover habitat for migrating birds effects of organic farming and landscape structure. Oikos 119: 1114-1125.

Davies NB 1977a. Prey selection and the search strategy of the Spotted Flycatcher Muscicapa striata, a field study on optimal foraging. Animal Behaviour 25: 1016-1033

Davies NB (1977b). Prey selection and social behaviour in wagtails (Aves: Motacillidae). Journal of Animal Ecology 46: 37-57

De la Hera I. Fontanilles P, Delalande L, Glad A,and Sarraude T (2017). Attraction of other species by bluethroat Lusscinia svecica song playback during autumn migration: an experimental test using bird-ringing data. Ardeola 64(1): 91-99

Delingat J, Dierschke V (2000). Habitat utilization by Northern Wheatears (Oenanthe oenanthe) stopping over on an offshore island during migration. Vogelwarte 40: 271-278

Devictor V, Julliard R, Clavel J, et al. (2008). Functional biotic homogenization of bird communities in disturbed landscapes. Glob. Ecol. Biogeogr. 17: 252-261.

Ellegren H (1990) Autumn migration speed in Scandinavian bluethroats Luscinia s. svecica. Ringing Migration, $11,121-131$

Eybert MC, Bonnet P, Geslin T, Questiau S (2004). La Gorgebleue. Belin, 71 p

Fontanilles P, Laval B, Diribarne M (2014). Sélection des habitats et occupation spatiale du Phragmite aquatique Acrocephalus paludicola sur une halte migratoire du sud-ouest de la France, mise en place d'une gestion intégrée. Alauda 82(4): 343-351

Fontanilles $\mathrm{P}$ (2014). Migration et régime alimentaire de la Gorgebleue à miroir dans les Barthes de 1'Adour, Actes du séminaire "Conservation des espèces et gestion des zones humides", Bayonne, 31 janvier 2014.

Fontanilles P, Chanchus B, Chauby X, De Franceschi C, Dufresne L, Fourcade J.M, Lapios J.M, Lartigau F, Legay P, Thouy P, Tillo S, Urbina-Tobias P, Short R \& Williams H (2012). Bilan du baguage des passereaux migrateurs et nicheurs sur les barthes de la Nive (Pyrénées-Atlantiques) en 2011. Le Casseur d'os, 12:80-84

Fransson T., Barboutis C., Mellroth R., Akriotis T (2008). When and where to refuel before crossing the Sahara desert extended stopover and migratory fuelling in first-year garden warblers Sylvia borin. J. Avian Biol. 39: 133-138

Freeman S, Jackson WM (1990). Univariate metrics are not adequate to measure avian body size. Auk 107 : 6974

Geslin T, Lefeuvre J.C. Le Pajolec Y, Questiau S, Eybert MC (2002). Salt exploitation and landscape structure in a breeding population of the threatened bluethroat (Luscinia svecica) in salt-pans in western France. Biological Conservation. 107: 283-289

Godet L, Marquet M, Eybert MC, Gregoire E, Monnet S, Fournier J (2015). Bluethroats Luscinia svecica namnetum offset landscape constraints by expanding their home range. J Ornithol $156: 591-600$ 
Godet L, Harmange C, Marquet M, Joyeux E, Fournier J (2018). Differences in home-range sizes of a bird species in its original, refuge and substitution habitats: challenges to conservation in anthropogenic habitats. Biodiversity and Conservation 27:719-732

Gottschalk TK \& Cover L (2016) Migratory and visiting birds in a maize field near Giessen, Germany in summer and autumn. Vogelwarte 54(1):1-14

Grueber CE, Nakagawa S, Laws RJ, Jamieson IG (2011). Multimodel inference in ecology and evolution: challenges and solutions. Journal of Evolutionary Biology 24: 699-711

Harris S, Cresswell WJ, Forde PG, Trewhella WJ, Woollard T, Wray S (1990). Home-range analysis using radio-tracking data - a review of problems and techniques particularly as applied to the study of mammals. Mammal Review 2 : 97-123

Harmange C, Godet L, Marquet M, Dietrich J, Monnet S, Grégoire E, Eybert MC, Fournier J (2016). [Unexpected movements of male Bluethroats Luscinia svecica namnetum during the breeding period] Déplacements inattendus chez des mâles de Gorgebleue à miroir blanc Luscinia svecica namnetum en période de nidification. Alauda 84 (3): 195-202

Hódar JA (1996). The use of regression equation for estimations of arthropod biomass in ecological studies. Acta Oecologica 17 (5): 421-433

Hutto (RL (2000). On the importance of en route periods to the conservation of migratory landbirds. Studies in Avian Biology, 20: 109-114

Jacobs J (1974). - Quantitative measurement of food selection: a modification of the forage ratio and Ivlevs' selectivity index. Oecologia 14: 413-417

Lindström C, Hasselquist D, Bensch S, Grahn M (1990). Asymmetric contests over resources for survival and migration. A field experiment with Bluethroats. Animal Behaviour 40: 453-461

Millennium Ecosystem Assessment (MA) (2005). Ecosystems and human well-being: Wetlands and Water synthesis. Washington, DC: World Resources Institute

Mohr CO (1947). Table of equivalent populations of North American small mammals. American Midland Naturalist 37: 223-249

Moore (FR), Mabey S, Woodrey M (2003). Priority access to food in migratory birds: age, sex and motivational asymmetries. In: Berthold P, Gwinner E, Sonnenschein E (eds). Avian migration. Springer-Verlag Heidelberg, Berlin, pp. 281-291

Musseau R, Herrmann V, Kerbiriou C, Bénard S, Herault T, Kerbiriou E, Jiguet F (2014). Ecology of Aquatic Warblers Acrocephalus paludicola in a fall stopover area on the Atlantic coast of France. Acta Ornithologica 49: 93-105

Musseau R, Beslic S, Kerbiriou C (2017). Importance of intertidal wetlands for the French coastal endemic Bluethroat (Cyanecula svecica namnetum) and conservation implications in the context of global changes. Ardeola 64: 325-345

Musseau R, Boutault L, Beslic S (2018). Rapid losses of interdidal salt marshes due to global change in the Gironde estuary and conservation implications for marshland passerines. Journal of Coastal Conservation 22(2): 443-451

Newton I (2008). The migration ecology of birds. Academic Press, London. Peris S. J., Mendes

Newton I (2004). Population limitation in migrants. Ibis 146: 197-226

Orłowski G, Rusiecki S, Karg J (2014). Partial dietary segregation between adult and nestling Bluethroats Luscinia svecica. Acta Ornithol. 49: 107-118

Pickering M, Wells N, Horsburgh K, Green J (2012). The impact of future sea-level rise on the European shelf tides. Cont. Shelf Res. 35: 1-15 
Piper WH (2011). Making habitat selection more "familiar": a review. Behavioural Ecology and Sociobiology, 65: 1329-1351

Poulin B, Lefebvre G, Mauchamp A (2002). Habitat requirements of passerines and reedbed management in southern France. Biol. Conserv. 107: 315-325

Provost P, Kerbirou K, Jiguet F (2010). Foraging range and habitat use by Aquatic Warblers Acrocephalus paludicola during a fall migration stopover. Acta Ornithologica 45: 173-180

Rappole JH, Warner DW (1976). Relationships between behavior, physiology and weather in avian transients at a migration stopover site. Oecologia 26:193-212

Saino N, Ambrosini R, Rubolini D, Harden-berg JV, Provenzale A, Huppop K, Huppop O, Lehikoinen A, Lehikoinen E, Rainio K, Romano M, Sokolov L (2011). Climate warming, ecological mismatch at arrival and population decline in migratory birds. Proceedings of the Royal Society, 278: 835-842

Salewski V, Kéry M, Herremans M, Liechti F, Jenni L (2009). Estimating fat and protein fuel from fat and muscle scores in passerines. Ibis 151: 640-653

Salewski V, Schaub M (2007). Stopover duration of Palearctic passerine migrants in the Western Sahara; independent of fat stores? Ibis $149: 223-236$

Schaub M, Schwilch R \& Jenni L (1999). Does tape-luring of migrating Eurasian Reed-Warblers increase number of recruits or capture probability? Auk 116: 1047-1053

Tellería JL, de la Hera I, Pérez-Tris J (2013). Morphological variation as a tool for monitoring bird populations: a review. Ardeola 60: 191-224

Tucker GM, Heath M (2004). Birds in Europe: Population Estimates, Trends and Conservation Status. BirdLife International. Cambridge

von Behren Christa R (2007). Impact of agriculture and urban development on the community structure of wetland birds in East Central Minnesota. Honors Projects. Paper 5

Whited D, Galatowitscha S, Testerb JR, Schikb K, Lehtinenb R, Husvethc J (2000). The importance of local and regional factors in predicting effective conservation Planning strategies for wetland bird communities in agricultural and urban landscapes. Landscape and Urban Planning 49: 49-65

Yong W, Finch DM, Moore FR, Kelly JF (1998). Stopover ecology and habitat use of migratory Wilson's Warblers. Auk 115: 829-842

Worton BJ (1989). Kernel methods for estimating the utilisation distribution in home range studies. Ecology, 70 : 164-168

Zanimetti JM (2005). - Statistique spatiale. Ed Lavoisier

Zuur AF, Ieno EN, Walker N, Saveliev AA, Smith GM (2009). Mixed Effects Models and Extensions in Ecology with R. Statistics for Biology and Health. Springer, New York, USA 